\title{
Creating community-inclusive organizations: Managerial accountability framework
}

\begin{abstract}
Based on a community psychology perspective, this qualitative study explores the community inclusion effort of one of the largest pulp and paper companies in the world. Extending the literature on workforce diversity/inclusion, we present the community inclusive organizational framework, which signifies the dynamics of community inclusiveness of organizations highlighting key managerial accountabilities (i.e., cultural, collective, relational and structural accountabilities) based upon the community psychology perspective. Theoretical and practical implications are presented for promoting community inclusive organizations, along with avenues for further research.
\end{abstract}

\section{Key words}

diversity, inclusion, community, business and society 
'This company is life for myself and my family...'

- Employee from a disenfranchised community

In the context of growing income disparities across the world, research has increasingly highlighted the significance of business and society working together to reduce disparities (George, McGahan \& Prabhu, 2012; Porter \& Kramer, 2006). Despite considerable efforts by nongovernmental organizations, private/public organizations and individual giving, approximately $20 \%$ of the global population (1.4 billion people) is still living on less than US $\$ 1.25$ per day (United Nations Development Program, 2013). We contend that large companies — given their economic power-can play a critical role in bridging the gap between the disenfranchised and the workforce (Mor Barak, 2013; Pearce, 2005). Companies have been criticized for their involvement in communities for business gain and for paternalism and insensitivity to local needs and voices (Muthuri, 2008). In the midst of the highly controversial role of companies in their surrounding communities, there is a growing expectation among media, activists, and governments for senior managers to be transparent in how they include/involve disenfranchised community members in their business processes (cf., Muthuri, 2008; Muthuri, Moon \& Idemudia, 2012; Waddock \& Boyle, 1995). We respond to this call. This study explores the concept of managerial accountability toward inclusion of disenfranchised communities in community-inclusive organizations based on the community psychology perspective (Trickett, 1996, 2009). We conceptualize managerial accountability as managers' norms and structural interventions that "bind social systems together," which in turn set social expectations for their role in a local community (Frink \& Klimoski, 2004, pp. 2; Hall et al., 2007). It further represents the managerial obligation or willingness to be "responsible for one's action and to let others examine one's actions" (Nelson \& Prilleltensky, 2010, p. 146). A disenfranchised community refers to the poorest socioeconomic group or those living at the 
base of the economic pyramid, deprived of employment, income, and education (Prahalad, 2009).

The company we selected for this study is not exempt from criticism of its managers' negligence of local needs. Asia Pulp and Paper (APP), one of the largest pulp and paper companies in the world, has received substantial negative publicity, which questioned its supply chain integrity and long-term impact on the environment and community for over 20 years (Gritten and Kant, 2007; Sonnenfeld, 2000). Yet in recent years, APP has received recognition for its effort to include local communities in its business processes, even from those who have criticized it in the past (Maitar, 2013; Reyes \& Manibo, 2014). In this context, our research question is: How can managerial accountability be conceptualized at the intersection of company and the disenfranchised community for creating a community-inclusive organization?

This research offers three theoretical contributions. First, our study departs from conventional approaches to inclusion as within-workplace activities to adopt a boundarycrossing concept that captures inside-out and outside-in inclusion between a company and its community based on a community psychology perspective (Fujimoto, et al, 2014; Trickett, 1996). The extant diversity inclusion/workforce literature commonly defines inclusion as minority members' insider status (Pelled, Ledford \& Mohrman, 1999; Shore et al., 2011); belongingness (Lirio et al., 2008); full contribution (Roberson, 2006), engagement (Avery et al., 2008); voice (Bell et al., 2011; Wasserman, Gallegos \& Ferdman, 2008); and participation in the organizational decision-making process (Mor Barak, 2013); as well as the means to draw out minority members' unique perspectives (Chavez \& Weisinger, 2008) and to integrate differences (Nishii, 2013) within a workplace. Although these studies on inclusion are critical for creating workplaces that value minority workers' contributions and participation alongside majority workers, research on the inclusion of disenfranchised communities-besides job 
networks and recruitment or representation efforts - has been somewhat neglected in this stream of research (cf., DiTomaso, Post \& Parks-Yancy, 2007; Fernandez \& Fernandez-Mateo, 2006). Only a few research efforts, so far, have examined innovative business practices that benefit underprivileged communities (George, McGahan \& Prabhu, 2012). Furthermore, most organizational efforts to promote diversity and inclusion have been devoted to establishing discrete work practices (e.g., recruitment, diversity training, mentoring, affirmative action programs) and have made few connections with the community context in which their business operates (cf., DiTomaso et al., 2007). Scholars have begun to explore business practices that benefit those at the base of the pyramid (George et al., 2012). However, there is a lack of normative organizational frameworks of inclusion that focuses on managerial accountabilities for integrating business and disenfranchised community for community growth. We fill this void by developing a community-inclusive normative organizational framework by exploring the underlying dynamics of community inclusiveness of organizations from a community psychology perspective. We draw from this perspective as it is concerned with how individuals feel, think and work together to improve individual and community lives through community interventions (Dalton, Elias \& Wandersman, 2007; Trickett, 2009), unlike the corporate social responsibility (CSR) perspective, which remains elusive, with competing and overlapping concepts such as corporate citizenship, business ethics, corporate community involvement, stakeholder management, and sustainability (Carroll \& Shabana, 2010; Matten \& Moon, 2008; Sweeney, 2007). Since diversity is a relational concept between different social groups embedded in the community (DiTomaso et al., 2007; Ragins et al., 2012), our study shows that inclusion is both multi-level and multi-dimensional, characterized by intersections between organizations and the community.

Second, we extend the trajectories of community engagement literature particularly in relations to its community empowerment (or transformational) strategies, which emphasize 
shared accountability between organizational and community members (Bowen et al., 2010; Rasche \& Esser, 2006). To date, community empowerment literature has produced different ideas of what organizations can do to empower community, such as proposing types of business participation in community (Boehm, 2005) and setting local criteria for community sustainability (Natcher \& Hickey, 2002). Stakeholder dialogue has been also discussed for reshaping organizational/managerial accountability, going beyond reporting of various accountability standards, which managers can control and therefore limits a scope of managerial accountability (Rasche \& Esser, 2006). Extending this line of community empowerment/stakeholder dialogue research, we propose a theoretically and empiricallyderived organizational framework resting on key pillars of managerial accountability (cultural, collective, relational, structural) to make organizations community-inclusive. We have identified cultural, collective and relational dimensions by triangulating our data with the community psychology perspective on inclusion and made an original contribution of adding structural dimension as the fourth dimension of managerial accountability. The structural dimension not only brings a new theoretical perspective into business and society, but also adds to that perspective by using a "business and society" case. The importance of structural dimension is also evident in applying the community psychology perspective to a large business like APP. Hence our contribution is reciprocal between community psychology and business/organization studies, highlighting how importing the community psychology approach extends the broader business and society literature thus heightening our theoretical implications.

Third, this research extends community psychology literature by developing a normative theory around the creation of community inclusive organizations. Based on the ecological perspective of community psychology and descriptive data from our study, we have developed a community-inclusive organizational framework that can be a basis to evaluate 
managerial accountabilities for community inclusion. As a whole, this framework is a unique addition to the existing discourses on inclusion, community empowerment, and community psychology by highlighting a new thinking in business and society nexus theorizing, moving away from one-sided organizational perspective of inclusion as being organizational led activities toward a holistic perspective of inclusion that connects organizations and disfranchised communities for mutual benefit.

The framework established in this study proposes managerial accountabilities that are likely to promote the inclusion of disenfranchised communities, due to manager-led organizational norms, culture, behaviors and attitudes (cf., Kalev, Dobbin \& Kelly, 2006). Through a contextual description of the exchanges between managerial processes and disenfranchised communities to improve community life, our findings show that alleviating poverty through business involves a set of managerial accountabilities that encourage changing the norms and behaviors of members inside and outside of organizations. Specifically, we introduce four dimensions of managerial accountabilities: 1) cultural, 2) collective, 3) relational, and 4) structural, to demonstrate that inclusion as a construct is not a result of discrete practices but an interrelated set of dynamics. Managers play a critical role in leveraging community strengths to improve business and community (cf., Nelson \& Prilleltensky, 2010). This framework can be used for a constructive stakeholder dialogue to challenge, question, and improve different dimensions of managerial accountability for mutual benefit (cf., Frink \& Klimoski, 2004; Schlenker \& Weigold, 1989).

\section{Community Psychology Perspective and Inclusion}

A hallmark of community psychology is its holistic and ecological perspective of valuing diversity and inclusion in the context of community (Trickett, 1996, 2009). It is concerned with the relationships between individuals and communities by understanding how individualsboth privileged and less privileged - feel, think and work together toward creating a better 
community (Burton et al., 2007; Dalton et al., 2007). It symbolizes the joint participatory process of individuals within organizations and surrounding deprived communities for improving community life as a whole (Dalton, et al., 2007; Moritsugu et al., 2014; Scott \& Wolfe, 2015).

By regarding accountability and holism as superordinate values applicable to the lives of the oppressed through holistic intervention by individuals, groups, organizations and communities, community psychologists assume shared values and synergistic collaboration among individuals across geographical boundaries (Fisher \& Shragge, 2007; Hawe, Shiell \& Riley, 2009; Nelson \& Prilleltensky, 2010; Trickett, 2009). Organizational members are therefore regarded as part of a societal system that is involved in multiple linkages and social interactions to improve the lives of disenfranchised community members outside and inside organizations (Hawe et al., 2009; Hirsch, Levine \& Miller, 2007; Kilby, 2006; Seidman, 1988; Trickett, 2009). By interacting with disenfranchised members, managers are expected to question their own community-related norms (attitudes, values and beliefs toward the community), resources (community strengths and social and economic opportunities in the community and organization), regulations (policies and routines to improve community life) and operations (equalization of power and decision-making in community and organization) (cf., Trickett, 2009). Accordingly, we regard managerial accountability for community inclusion to consist of managers' response to eradicate the state of community poverty and their interventions to ensure that business processes play a role in improving the lives of people in the disenfranchised community.

One view, as inferred by community psychologists, is that organizations are responsible for reducing the power imbalance between advantaged and disadvantaged groups in society (Himmelman, 2001; Nelson \& Prilleltensky, 2010; Trickett, 2009). By depowering organizations' advantaged positions and empowering disenfranchised communities, 
community psychology promotes the "affirmative diversity" of organizations in using their power to maximize the "uniqueness, special qualities, strengths and positive characteristics" of the disenfranchised community (Nelson \& Prilleltensky, 2010, pp. 142). Organizations are expected to empower surrounding communities, moving from accepting a society of conformity to accepting one of diversity through inclusionary and reciprocal relationships between the privileged and the less privileged (Harrell \& Bond 2006; Rappaport, 1995; Trickett, 1996). To date, community engagement/empowering research within the developing regional context is limited to validating the importance of community driven approach. A number of scholars have criticized a narrowness of managerial approach in addressing multiple issues related to developing regional contexts such as weak institutions, high level of poverty and competing interests of stakeholders (e.g., Head, 2007; Sherman \& Ford, 2014). We develop an organizational framework of inclusion for integrating business and disenfranchised community for community growth that illustrates the need for four types of managerial accountabilities, taking into account the unique contextual issues of developing regions - weak institutions, high level of poverty and competing interests of stakeholders.

\section{Managerial accountability and Inclusion}

In the context of growing income disparities across the world, research has increasingly highlighted the significance of business and society working together to reduce disparities. Drawing on the value and normative perspective of community psychology, we examine managerial accountability for organizational inclusion at the intersection of organizations and disenfranchised communities (Nelson \& Prilleltensky, 2010). In order to relate community psychology literature into business-society working together to promote inclusion, we have adopted three tenets from the community psychology literature in theorizing community 
inclusive organizations as follows: (a) community inclusion perspective (b) empowerment evaluation by community and (3) organizational role for community inclusion.

We define inclusion as a function that may not be a result of discrete practices (Hirsch et al., 2007; Levine \& Fitzgerald, 1992). Instead, we regard it as a dynamic social and ecological process of inside-out and outside-in inclusion between an organization (inside) and the community (outside). From the community psychology perspective, inclusion is often acknowledged as a multi-level and dynamic concept referring to the inclusion of disenfranchised community members. We propose that multiple dimensions of inclusion, with a notion of empowerment evaluation widely supported by community psychologists (Fetterman \& Wandersman, 2007) may assist stakeholder dialogues in evaluating community inclusion of organization with a sense of mutual ownership and responsibility (Fetterman, Kaftarian \& Wandersman, 1996; Scott \& Wolfe, 2015). By taking part in this process, organizations will improve their role for community inclusion by learning new ways of doing business by "designing new policies and programs, carefully monitoring these, evaluating their overall effectiveness, and reflecting on lessons learned for the future" (Dalton et al, 2007, p.124)

The fundamental belief behind empowerment evaluation is that "community members are the experts on their community" and that they have "a right to make decisions about actions that affect their lives and direct the evaluation process" (Dalton et al., 2007 p. 489). Hence, they should be included in corporate decision making process that concerns the wellbeing of community life. Further, empowerment is of central value in community psychology literature with expectation of community members to take part in evaluation and implementation of projects/inclusive initiatives (Zimmerman, 2000). With this understanding, inclusion within community psychology is recognized as the individual, collective and relational empowering phenomenon, which acts as a useful multi-level framework for stakeholder dialogue for joint 
improvement (Nelson \& Prilleltensky, 2010, Rasche \& Esser, 2006). Against this backdrop, we present propositions for managerial accountabilities toward developing community inclusive organizations.

Inclusion at the individual level refers to the "development of "personal story of empowerment" (Nelson \& Prilleltensky, 2010, p137). The personal empowerment entails development of positive identity, positive energy and personal control within an individual life. We view that personal empowerment is an ultimate goal of community inclusive organizations since how organizations include community empowers individuals inside and outside organizations via energizing and reshaping their identities regarding their role in life (c.f., Wandersman et al., 2004). Empowerment may include intentional organizational processes that leverage positive aspects of community situations so as to improve both organizational and community operations (Zimmerman, 2000). Hence we propose:

Proposition 1: Managerial accountability for developing community inclusive organizations involves individual empowerment outside and inside organizations.

At the collective level, inclusion refers to individuals' access to valued resources or the attainment of employment, income and education collectively. It entails capability building of individuals and groups by creating employment, income and education, which reciprocally empowers individuals and interpersonal relationships inside and outside organizations through effective working relationships (Zimmerman, 2000; Nelson \& Prilleltensky, 2010). This level of inclusion becomes more achievable through organizations and other institutions that are committed to help ameliorate social inequalities in society (Dalton et al., 2007). Hence, we propose: 
Proposition 2: Managerial accountability for developing community inclusive organizations involves collective empowerment of members across organizations and communities through a creation of employment, income and education.

At the relational level, inclusion refers to individuals' positive relationships and collaborations with others (i.e., relational empowerment), including the acquisition of emotional support, guidance and financial support (Nelson \& Prilleltensky, 2010). This relational aspect of inclusion entails organizations proactively searching for strengths in community by collaborating with the community members rather than predetermining their action for community development (Zimmerman, 2000). By placing disfranchised community members as a central process of collaboration, organizations become a resource for surrounding disfranchised communities by seeking to understand their world views and struggles (Zimmerman, 2000). The relational inclusion promotes deliberate, democratic and authentic collaboration that maximize the use of the skills and knowledge in the community (Dalton et al., 2007). Hence, we propose:

Proposition 3: Managerial accountability for developing community inclusive organizations includes relational empowerment of members across organizations and communities

Although not specified as being part of inclusion process by community psychologists, we anticipate that a process of organizational empowerment on the community will entail organizational governance or structural process that ties in the multiple dimensions of inclusion at the individual, relational and collective levels (Peterson \& Zimmerman, 2004). Based upon the empowerment evaluation principle, which promotes accountability to evaluate programs 
from multiple lens (Wandersman et al., 2004), we anticipate that organizational members from different levels of hierarchy will be involved in planning, decision making and evaluating process to ensure that inclusion process is both a top down and a bottom up process (Dalton et al., 2007).

Proposition 4: Managerial accountability for developing community inclusive organizations involves an organizational governance or structural intervention that ties in the individual, the collective and the relational empowerment across organizations and communities.

We propose that these dimensions of inclusion may serve as a foundational framework for developing normative theories around managerial accountabilities in developing community inclusive organizations. By exploring and describing the community inclusive efforts of APP which may be empowering or non-empowering, we seek to develop a generalizable organizational framework for understanding community inclusiveness of organizations (Zimmerman, 2000) in developing countries/regions.

\section{Method}

This study is best described as theory elaboration (Lee, 1999). It expands upon theoretical links that have received little attention among workforce diversity scholars (e.g., Mor Barak, 2013; Ragins et al., 2012). Previous research on inclusion mainly examined the phenomenon of inclusion inside an organization and did not sufficiently explore the managerial accountability of inclusion at the cross-section of an organization and a disenfranchised community. Therefore, we chose the research setting on conceptual grounds, rather than representativeness, in order to examine the central concepts regarding the creation of community-inclusive organizations (Jacobides, 2005; Miles \& Huberman, 1994, p. 27). 


\section{Research Setting}

For the purpose of our research, we have selected the social context of a developing nation in which business operations are embedded in disenfranchised communities. We selected Indonesia, which consists of a large population with a rapidly growing economy, yet, in which social inequality remains a critical issue for the country (Miranti et al., 2013). Specifically, our study examined the community inclusion effort of APP, which is one of the largest pulp and paper producers in the world. It manages its entire supply chain, from tree plantations, converting fiber and wood into pulp, paper, tissues, packaging, and stationery products, and sells paper products in more than 120 countries on six continents (APP, 2013a). Despite the fact that APP has been the subject of substantial negative publicity, questioning its supply chain integrity and its long-term impacts on the environment and community (Gritten \& Kant, 2007; Sonnenfeld, 2000), favorable reports on APP's community involvement have emerged recently. The reports include the rolling out of a long-term environmental sustainability plan with community development projects (Shankleman, 2013). Given this change in behavior, we have selected APP as a suitable company through which to explore the concepts of community inclusion of organizations in various locations. Today, APP's vision is to become the $21^{\text {st }}$ century's premier world-class pulp and paper manufacturer that exhibits sustainable business growth, environmental sustainability and contributes to poverty reduction in Indonesia (APP, 2013a). The corporate team at APP is committed to ensuring that the operation of their supply chains has positive impacts on the social and economic welfare of the surrounding communities (APP, 2013b). For the past ten years, APP has created various managerial roles at its headquarters (HQ) and supply chain sites to include community members in its operations.

We examined two of APP's seven pulp and paper mills and its exclusive supplier of raw materials-Sinarmas Forestry-which has embedded community inclusive projects (Yin, 2003). Sinarmas Forestry is the exclusive raw material supplier to all seven pulp and paper 
mills. The first mill we examined is Indah Kiat Perawang, which is APP's largest mill that specializes in converting raw materials into pulp and paper. The other mill-Indah Kiat Serangspecializes in creating the final paper products from pulp that is transported from Indah Kiat Perawang. It also recycles used paper sourced locally in Indonesia and from other countries. We primarily focused on APP's community-inclusive projects within these sites, which reaped meaningful benefits for the surrounding communities and APP's business- transforming value chain activities (cf., Porter \& Kramer, 2006).

\section{Procedure and Sample}

Data collection for the study involved three stages between 2012 and 2013. In the first stage, in the year 2012, the authors visited APP in Jakarta to conduct a feasibility review, followed by a preliminary meeting with APP officials before conducting the field research. We undertook a detailed document review of the company's inclusive projects from publicly and privately available materials-namely, community project listings, annual reports, sustainability reports, and websites.

Based on APP's internal reports on community projects (APP, 2013c), we found some projects to offer meaningful benefits for the community in terms of providing education, employment, and income generation. Randomly, we selected some educational, skill development and income generation projects as exemplar activities to explore whether or not these activities were meaningful in terms of community inclusion from the community psychology perspective.

In the second stage, the research team undertook site visits as well as conducted interviews of key stakeholders inside and outside of the organization, over a ten-day period in March 2013. We collected evidence from multiple sources: interviews, focus groups, presentations, archival data, APP publications, and field notes. In total, we interviewed 92 stakeholders related to APP's community-inclusive activities across: (1) the HQ office, in 
Jakarta, Java Island; (2) Sinarmas Forestry in Perawang, Sumatra Island; (3) the Indah Kiat Perawang Mill on Sumatra Island; and (4) the Indah Kiat Serang Mill on Java Island. Interviews with all managers $(\mathrm{N}=10)$ and employees (non-beneficiaries $\mathrm{N}=7$; beneficiaries $\mathrm{N}=6$ ) were conducted in English. For community beneficiaries $(\mathrm{N}=24)$ and non-beneficiaries $(\mathrm{N}=30)$, we had local translators with us to translate our questions and their responses on the spot. In the third stage, in May 2013, additional interviews were conducted with employee beneficiaries $(\mathrm{N}=15)$. We also gathered 36 local newspaper articles on APP between 2004 and 2012 for content analysis.

In the second stage, in which the majority of data was collected, we began our interviews with the managing director who oversees the sustainable and stakeholder engagement division at HQ. We started with the following question: “What is your perspective on APP's journey toward sustainability?" We explored top management's perspectives regarding community inclusion as much as possible by probing for clarifications and actual examples. Most of the interviews with managers involved an open-ended format so as to explore their perspectives on APP's journey in developing community inclusivity along its supply chain. We deliberately did not ask specific inclusion questions but, instead, allowed participants to talk to us about it. Only at the end of each interview did we ask them what they meant by inclusion. At the three research sites, each manager began with a presentation on their community development efforts, which was followed by our interview. Including the time for the presentation, the interviews took approximately one to two hours each. The interviews with community members and employees were quite short; we randomly interviewed them in casual settings or during their work activities. Each interview took approximately 10 minutes and each focus group took approximately 20 minutes. All the interviews conducted at all sites were audio recorded with the consent of the participants. We asked open-ended questions, such as, "What do you think of the Mill?" "Do you feel included by the Mill?" "Did you benefit from their 
community activities? If so, how?" "How did your life change by being involved in such activities?" and "Has the Mill consulted you before the management team undertook social support activities?" Although interviews conducted in Indonesian were translated back to us on the spot, we asked our Indonesian research assistant and Indonesian academic to conduct a back-to-back translation to ensure that the interviewees' voices were accurately interpreted.

\section{Data Analysis}

We sought to explore the perspectives of key social groups that influence or are influenced by APP's community-inclusive activities (Donaldson \& Preston, 1995; Freeman, 1984). Our analysis included perspectives of managers and employees (beneficiaries and nonbeneficiaries) and disenfranchised community members (beneficiaries and non-beneficiaries) to make sense of APP's managerial accountabilities for creating community-inclusive organizations. The core objective of our analysis was to draw the participants' understanding of common experiences regarding community inclusive initiatives and managers roles APP's archival data (e.g., annual report and sustainability report) and newspaper articles were particularly useful in confirming, complementing or disconfirming the perspectives that we obtained from our field study. During our analysis, therefore, the authors frequently assessed new findings against the archival data. We used a community inclusion perspective from community psychological literature to analyze the data, focusing on its inclusion theory on inclusion, collective and relational levels of inclusion, as a broad framework for thematic analysis. For example, we identified the individual level of inclusion for organizational members as well as beneficiaries, and included other related themes such as the changing value of individual managers and employees. We categorized this finding to managerial accountability and labeled it as cultural accountability. When our findings were considerably different from the inclusion theory, from a community psychology perspective, we created a 
new dimension of inclusion and related it to managerial accountability. Specifically, we identified structural inclusion and created a dimension of structural accountability. A research assistant, blind to the purpose of this study, was appointed to count quotations from all sources of secondary data for each sub-theme. A second research assistant was asked to count quotations for the subset of each data source for verification. Approximate inter-rater reliability across two research assistants was $80 \%$.

\section{Findings}

Our data identify multiple levels of inter-related dimensions of managerial accountability that enhance APP's community inclusion along with the challenges faced in this process. These dimensions of managerial accountability have been termed: (1) cultural accountability; (2) collective accountability; (3) relational accountability; and (4) structural accountability. We report each accountability dimension along with their associated challenges below.

Managerial cultural accountability. Our findings suggest that, for those who are involved in community-inclusive activities as givers or beneficiaries, the community-inclusive culture within organizations shared and facilitated by managers have empowered their positive identity, self-esteem, and the attainment of control in their circumstances. Organizational culture is often acknowledged as a set of common mental assumptions that guide norms (i.e., values, beliefs, and attitude) that has been learned and passed on to guide appropriate behaviors inside and outside organizations (Ravasi \& Schultz, 2006; Schein, 1984). Managers' value on cross-cutting organization and community growth was presented at APP; along the following lines: "As communities prosper, the company will become stronger" (Sinarmas Forestry), and "We give resources to the right people at the right time for the right purpose, which leads to community prosperity, including our own business operations” (Indah Kiat Serang). By participating in APP's community-inclusive practices, the majority of managers (60\%) shared 
a new pattern of perceiving, thinking and feelings (Schein, 1984) inside and outside of work domains. The following quotes demonstrate:

These inclusive activities are really influential for my personal life. Why? Because I can see how lucky I am, and I am also grateful that I have a proper job, being here creating empathy in me, not only in me but also with my kids and my family. And we have to do good things to others to help everyone. That's how I raise my kids now - manager, the Serang Mill.

When I got into this position, I looked at it as something unimportant. After I met with [disenfranchised] people, I realize that this is a very good position for self-actualization and how to raise people with basic needs to become wealthier. I am very happy to see those people getting benefits out of it - Head of Corporate Affairs and Communication, HQ.

At the Serang Mill, where employees donate a part of their income to support disenfranchised

children's education, managers and employees have also shared a similar pattern:

Before 1997, there was the philosophy that not only company helps the society but employees as well. We donated 200 million rupiah [US\$20,000] from 1000 employees. This is a powerful message to tell the community, we, 'the employees,' are part of community. We tell to the employees, the most important thing about donation is that it comes from the heart. So, this aspect of togetherness, care and concern comes from our big family, Serang Mill to community - manager.

Sharing what we have with others, funding the poor children is something amazing. I can feel this mainly for the communities around us. I support 6 kids, 2 elementary school students, 2 junior high school students and 2 senior high students - employee.

Every month, I am given invoice from a public affair including my sponsored children pictures, so I know who I support. It touches my heart - employee.

Reciprocally, the community beneficiaries reported that their lives have been empowered. When we asked sponsored children about their school experience, most of them echoed "It's lots of fun", and many shared their dreams. These person-to-person acts of giving that take place across organizations and the surrounding community (e.g., one employee to one child) tells a powerful story of empowerment and transformation at individual, group, organizational and community level, thus reinforcing the community-inclusive culture of the organization. The beneficiaries also reported on positive relationships with company staff (i.e., a relational level of inclusion), as well as the receipt of valuable resources (e.g., education) for 
their independent livelihood (i.e., a collective level of inclusion). The employees from the disenfranchised community (who were sponsored by APP to study at the company school) further shared exemplary phenomenon of "inside-out and outside-in" cultural accountability of managers/organizations:

After being in this company, my life has changed for better and then I got into this school and obtained more knowledge. My attitude has changed. I am motivated to develop other businesses as being taught in the school

. Our findings stress the importance of managerial cultural accountability where managers share and practice a value-driven approach to include community as an inherent part of organizations, which in turn empowers individual givers and beneficiaries. Since cultures may encompass subjective meaning of inclusion, we regard managerial cultural accountability as most influential in determining subjective interpretations of personal empowerment. Expanding Proposition 1 in light of a managerial accountability, we therefore propose cultural accountability of managers, for fostering individual empowerment outside and inside an organization.

Our findings also suggest some potential challenges of cultural accountability in terms of not being able to produce empowerment of beneficiaries, particularly in the unique contextual realities of developing countries. For example, several managers expressed that they "know the importance of identifying community strengths and the need to help them', however, "some (individuals) are unwilling to work". As the concept of accountability involves identification of who can call on whom to accept responsibility for actions (Day \& Klein, 1987), cultural accountability needs beneficiaries' reciprocal efforts in appreciation of the support they receive for their independence and positive identity. This is reflected in our findings where cultural accountability promoting the community inclusive activities created dependence rather than empowerment among some community members, mainly due to lack of education and awareness- that reflects one of the challenges of a developing country context. 
This, therefore, highlights the importance as well as the need for educating and developing awareness among the community members and managers about "helping people to help themselves" for meaningful and sustainable outcomes for communities and businesses (Scott \& Wolfe, $2015 \mathrm{p}, 334)$.

In light of our findings, therefore, managerial cultural accountability involves multiple public reporting of subjective transformation of individuals including: (1) value communicated by managers and companies on cross-cutting organization-community simultaneous growth; (2) stories of personal empowerment by those involved in and impacted by community inclusive initiatives of organizations and (3) changing values of managers and employees in relation to their roles and responsibilities in work and non-work life (see Table 1). Table 1 provides a summary of sub-themes with sample quotes for cultural accountability. APP - in light of long standing land conflicts and being the largest concession holder in Indonesia - will need to continually communicate their cultural accountabilities to community members and more stories or reports of personal empowerment need to be told by outsiders. Recently, APP's newly appointed Vice President of Corporate Affairs has acknowledged that APP will 'take time to build up trust again' (Jagdish, 2016).

Managerial collective accountability. Drawing from our findings and integrating them with inclusion at the collective level relating to groups' access to valuable resources (e.g., employment, income and education), we report that the collective accountability of managers as collectively enhancing valuable resources, such as employment and education for the community, which also benefit the business (APP, 2013d). For example, the managers' presentations explicitly stated that they "strengthen the company position as a center for economic, socio-cultural development of surrounding communities (Perawang Mill) and "build 
business based upon economic consideration to guarantee the peaceful community around the operation" (Sinarmas Forestry).

We have witnessed evidences of managerial collective accountability by visiting its sponsored schools inside and outside their mill operations. A teacher in APP's vocational school in Perawang, which enrolls over 4,000 students mentioned:

This school is getting better all the time. APP makes a big difference in the local community, in the lives of people. Previously, people didn't send their children to a school, but now we have the school so most of students here - the kids and teenagers go to school. Most of them don't drop out. So, many students from here continue studying to university, even very good university in Indonesia.

In order to enhance the employability of the students, the curriculum includes machinery, electrical, computing and other pulp and paper and forestry subjects. By visiting the school, we witnessed the positive vibes among the students. Those interviewed mentioned that the school is lots of fun and that they had aspirations to become professionals (e.g., machinery engineer, programmer, doctor). In addition to supporting educational activities, APP was also providing "on-the-job" training programs. Such programs are where universities and vocational high schools from the surrounding communities and other cities can send their students to learn first-hand pulp and paper-making skills under the guidance of skilled and experienced practitioners (APP, 2013e). While these initiatives help the community to become more skilled and employable, they also help APP to get a skilled and trusted workforce. This project exemplifies the inside-out and outside-in economic developmental activities between APP (inside) and the surrounding communities (outside). There were a number of other insideout and outside-in activities that interviewees reported. Two APP community development managers gave the following examples where the community impact has been substantial:

Seedling farm: We provide seeds to the community; then, with monitoring by our staff, produce seedlings in 3 months. We buy their seedlings for our tree plantations. So, it is a mutually beneficial relationship. 
Fishpond: It's the whole community - many members who were previously illegal loggers depend on the fishpond we set up. We went to them and raised their awareness that what they were doing (illegal logging) was not sustainable and not good for them, as well as not good for us. The village right now has a sustainable practice. We support them to develop the fishpond and market the fish so they don't have to do illegal logging.

The seedling farm initiative for example, in a span of five years (2007 - 2012) grew from 120 people involved in 90 seedlings to 797 people involved in 6333 seedlings. It has further trained community members to produce seedlings for 102 species and 38 varieties of fruit. Community nursery program also provides: seedlings of fruit trees to participants after training; free technical advice for fertilizer application to the farmers; and monitoring the fruit trees planted by the local community in the first year. APP also provided basic necessities for community to operate, particularly improving ecological infrastructure of community (e.g., road, electricity supply and healthcare) which, in turn, benefited their business operations. The collective accountability of managers is further confirmed when the majority of managers (60\%) defined inclusion as a joint socio-economic activity between organizations and communities:

Inclusion is dependent on how the corporation puts socially inclusive policies together on how it is doing the business. Whatever the corporations are doing in terms of business or social economic activities, they should consider their impact on the community - manager, HQ

Inclusion is when community around business is working as our employee or contractor - manager, Serang Mill.

These accounts support our Proposition 2 regarding collective empowerment across organizations and communities. However, in light of much environmental and community damages done by APP with the heightened community expectations toward APP's social responsibilities, APP's community initiatives runs the risk of being one-sided. This situation is further complicated by the domination of philanthropic approach to CSR in Indonesia like in other developing countries that involves donations and one-off community initiatives, based 
on ad hoc decisions as opposed to more systematic assessment and prioritization of stakeholders needs (Jamali, 2007). For example, a householder community member reported that, besides the road maintenance, APP also needed to fix the driveway for her property. Another community member reported his desire for APP to provide a sporting facility as provided for APP staff within the mill. In the context of the dominance of philanthropic approach of CSR, such evidences show that the joint evaluation and decision making of organizational and community members are necessary in communicating each other's expectations, amending differences and ascertaining the sort of activities that benefit community and organization (Dalton et al., 2007).

Managerial collective accountability therefore involves multiple evidence of joint resource maximization through constructive dialogue between organization and community including (1) community and employee beneficiaries acquiring employment, income and education through organizational initiatives, which extend to organizational growth (2) ecological infrastructure (e.g., roads/electricity) and basic needs of community (e.g., healthcare) being supported by organizations for mutual benefit and (3) communities surrounding business operations being supported by organizations through community centers or facilities so as to strengthen the company position as a center for economic and socio-cultural development of surrounding communities (See Table 1). Table 1 provides a summary of subthemes with sample quotes for collective accountability.

\section{Insert Table 1 About Here}

Managerial relational accountability. Drawing from our findings and integrating them with inclusion at the relational level, our data indicate the relational accountability of managers as facilitating positive relationships with disenfranchised community members and leveraging 
their special qualities (or skills) for mutual benefit. APP recognizes that sustainability of its operations is "to consider communities as friends and, in turn, to do something good for them" (Manager, Perawang), and is "closely related to how the company can work together in equal partnership with community members" (APP, 2013b). In order to develop collaborative relationships, local staff members were appointed at each mill site who were "very strongly committed to community development and capable of talking with local leaders, local governments and knowing local people by name”.

Notably, most community beneficiaries reported their feelings of inclusion, in particular, making reference to face-to-face informal relationships with company staff, such as, "Yes, I feel included. He (the APP staff member) visits me almost every one to two weeks for informal chats" (male, farmer); and "Yes. He visits us and talks to us every week and we can discuss the materials" (female, paper craft). Reflecting the relational accountability of managers, most of them (70\%) expressed the concept of inclusion as a form of mutual communication:

Inclusion - I think it is two ways, I think it's communicating each other's needs, basically good communication. It means basically communicating what we mean, understanding what they mean and find out some basis where we reach mutual understanding - manager in HQ.

Most managers (70\%) also elaborated on the concept of inclusion as "multi-stakeholder engagement" with local governments, non-government organizations (e.g., Greenpeace) and local communities as a means of finding an effective way to develop community lives. In addition to evidence on APP's relational accountability, we also found community reporting that invokes questionable progress in this domain. In relations to APP dealing with land conflicts, an independent field survey has reported little change for communities involved in land disputes with the exception of two communities, calling for greater transparency and building positive relationships with stakeholders on the ground (Cortesi, 2015). Although all of the beneficiaries inside and outside the company reported inclusion, our data also gathered 
that non-beneficiary community members who lived around the mills did not report the same sense of inclusion. While some were grateful to the company for increasing employment opportunities, there was more negative than positive reporting, especially from women who felt that they were not consulted about their needs. Although these negative accounts can be explained by non-beneficiary members not being materially dependent on APP (which made them speak more freely), they also reflect their sense of dependency and expectations towards APP on one hand and the pressing socio-economic needs of the community members in developing region and the likely challenges for companies to satisfy their expectations, on the other hand.

Despite APP conducting inclusive community activities, such as education, handicraft making, road services and farming, ambivalent voices from non-beneficiary community members imply that more creative approaches are necessary to develop a greater sense of relational inclusion surrounding its operations. A manager in charge of stakeholder engagement also acknowledged that APP needs to improve communication externally (to community) and internally (within organizations) to create more community awareness and engagement.

Despite of relational controversies, organizations such as Greenpeace have begun to report that APP is taking steps to address the issues (Jagdish, 2016). From our data, APP staff -by talking with some community members utilized the unique skills of women to be engaged in handicrafts using the industrial waste of APP, which were then used to empower community and company growth. A local community manager in Serang mentioned the paper craft project:

This product [paper craft] is not our innovation. They (the community group) produced it, but they just kept it quiet. They don't have any confidence. We increased their confidence by saying that this is a valuable product and this product is going to be very successful and they'll get additional income. We made them believe that what they have produced is a good work. This product was presented to the wife of the minister and was highly appreciated. Then they got strong confidence. 
This finding also aligns with the concept of inclusion in the management literature, which suggests that minority members feel included by being accepted and appreciated for their unique characteristics for the collective good (Shore et al., 2011).

The paper crafts prepared by disadvantaged women using industrial waste are currently used for APP's marketing and are also given to visitors. APP has also been investigating marketing opportunities for their paper craft products (e.g., tissue boxes, note books, ornaments) to broader markets, with their logo on every product. Managers also shared examples of some unique characteristics of particular ethnic groups such as Javanese immigrants' farming skills were identified as being superior to those of local Sumatran farmers.

Another noteworthy feature of relational inclusion identified in this study is that the Serang Mill which exerted most effort in relationship building and giving in community (e.g., paper crafts, medical services, and child sponsorships, schools inside and outside of the mill) has also shown positive relationships inside the Mill. One of the managers reported:

By employee giving donations to community, it creates harmony amongst the employee. Its effect is amazing. The company and employees can be more calm, polite to each other and toward the community.

The employees interviewed in the Serang Mill also reported that there have been hardly any conflicts inside the mill. Through our site visits, we also witnessed a general sense of family-like relationships among employees. For example, one of the employees mentioned that "nothing belongs to me, all of us have feeling of belonging to each other. Employees don't feel hindered by helping communities. We are supported by our managers". Most of the employees' beneficiaries who attend the company school $(\mathrm{N}=18 / 20)$ also reported a feeling of inclusion as being part of a big family such as "Yes, I feel included as a big family of Serang Mill, I am included in every problem. I can share my opinions", "the communication is good amongst manager and peer especially when there is problems that can be discussed", "in terms of giving opinion, my manager listens to me", and, "I meet with managers directly and get 
response”. Most of them also defined inclusion as companionship within a workplace, using terms such as "teamwork" and "friendship" in a slightly different way from the existing concepts of inclusion in a workplace. In the communal culture of an Indonesian workplace, inclusion is usually seen as sharing each other's workloads and burdens informally, rather than the extant formal inclusion concepts of executing equitable employment practices and inclusive organizational decision-making practices.

Aligning with Proposition 3, community inclusion entails relational empowerment amongst individuals across organizations and communities. Managerial relational accountability therefore involves building trust, connection and participation in a holistic way with various community groups involving: (a) identifying and leveraging special qualities of ethnic groups through micro-relationships on fields; (b) executing on-going mutual communication between organizations and disenfranchised community beneficiaries and nonbeneficiaries; (c) stakeholder relationship building (i.e., NGOs, government officials, medical experts) to improve community life; and (d) positive and supportive relationship inside those operations that actively engage and empower community. Table 1 provides a summary of subthemes, with sample quotes for relational accountability.

Managerial structural accountability. As noted by a HQ manager- “our supply chain is our responsibility"-most managers emphasized the importance of structural alignment along supply chains by setting community development targets, executing planning cycles, assessing deliverable projects and selecting sustainable, inclusive projects. Drawing from our data, we propose managers' structural accountability as organizational structural governance to distribute socio-economic and political power to the communities along the supply chain (cf., Edwards \& Sen, 2000; Kilby, 2006). In line with Proposition 4, this structural governance facilitates inclusion at individual, relational and collective levels. APP has taken both top-down 
and bottom-up structural interventions to equalize power relations between it and the community. For example, the head of the stakeholder engagement division described the overall strategy being driven by $\mathrm{HQ}$, which is that each project is managed at each mill to grant them a sense of ownership. Being grounded in the principle of the United Nation's Millennium Developmental Goals, HQ managers listened to the aspirations of individual mill managers, as well as received input from independent parties (e.g., non-governmental organizations, NGOs) on the kinds of support that their communities needed and undertook an evaluation of current activities. Managers at HQ further explained the annual planning cycles of a dialogue between HQ and the local mills on the "what, when, where, why and how" of each project proposal in order to set priority projects and plan a roadmap with impact measurements for each project. While HQ managers emphasized the organizational monitoring process of community development, local mill managers emphasized the selection criteria of the beneficiaries. For example, the Serang Mill sets the criteria for employee beneficiaries to enroll in the company school, such as, having to obtain high job performance (Grade A or B); having to pass the interview with teachers and managers; and obtaining permission from their department head and wife.

APP is, however, still working on quantifying what return on investment they have been getting from inclusive projects. Nevertheless, in support of Proposition 4, APP's structural accountabilities for community-inclusive projects were evident in the coordination of HQ and other supply chain sites to transform community life. However, employees who were assigned to oversee inclusive community projects were responsible for multiple tasks and, in fact, often the community relationship-building process was seen as secondary to their main job. As a result, being responsible for multiple jobs, they were not always managing their community initiatives as they wish. Table 1 provides a summary of sub-themes with sample quotes for structural accountability. Structural accountability involves tying cultural, relational, 
and collective accountabilities including (a) reporting between HQ and community sites (b) setting selection criteria for beneficiaries (c) determining social investment measures and (d) appointing a staff in each local operation solely for community empowerment (See Table 1).

\section{Discussion and Conclusion}

For the past few years, it has been argued that companies have focused too much on short-term economic gains, overlooking the attempts to include community in business activities (Vurro et al., 2009). Community psychologists around the globe argue that core values of many business activities are being taken out of context (Nelson \& Prilleltensky, 2010, p. 52). In order to make a significant turn away from accepting organizations based on market capitalism to creating organizations with compassionate capitalism, some scholars and practitioners are promoting a new organizational approach of doing well by doing good (Benioff \& Southwick, 2004). Large organizations can play a vital role in attenuating the significant and disproportional gap between the wealthy and impoverished population in society (Pearce et al., 2005). By organizations taking an ecological perspective, their inclusion ideology will inherently consider the consequences of their actions for communities while solving the issues of the disenfranchised community. Our findings on randomly selected exemplary community inclusive projects at APP has demonstrated the evidence of four key managerial accountabilities that facilitated the organizational inclusion of community. We further argue that these managerial accountabilities through stakeholder dialogue will help APP and other organizations to deal with challenges arising from the unique context of developing countries and their dominant philanthropic approach that has created dependency among the community members raising their expectations. Drawing from our findings, we propose a normative theory around four key managerial accountabilities for creating community-inclusive organizations as shown in the community inclusive organization framework developed in Figure 1. 


\section{Insert Figure 1}

To promote inclusion for organizational and community prosperity, our findings suggest that the managers need to obtain a perspective of community inclusion beyond internal organizational inclusion within the workplace. By incorporating our descriptive data obtained from APP, we introduce four managerial accountability types which create inclusion at multiple levels: individual, collective, relational and structural. First, we introduce managerial cultural accountability (i.e., shared mental assumptions and norms), which facilitates crosscutting organizational and community growth, and transcends into "individual stories of empowerment" as givers and beneficiaries (cf., Nelson \& Prilleltensky, 2010, pp. 137). In Figure 1, cultural accountability is represented as an inner circle of the framework, most relevant to the individual level of inclusion. Individuals being empowered as givers or beneficiaries is often the result of their participation in community-inclusive activities with relational (positive relationships) and collective levels of inclusion (receiving resources for independent living or company operations). Second, relational accountability is introduced within the inner ellipse close to cultural accountability, in Figure 1, fulfilling the relational level of inclusion at the intersection of organizations and disenfranchised communities. Going beyond positive relationships, managers promote affirmative diversity (Trickett, 1996) by talking with disenfranchised community members to capitalize on the skills of beneficiaries and leverage them for community and business prosperity (relational level of inclusion), while also influencing the individual (e.g., personal empowerment) and collective level of inclusion (e.g., more income for disenfranchised individuals and a new product for a company). The mills that positively interact with a disenfranchised community through donation, employment and education, facilitate relational inclusion within the company, promoting harmony and 
family-like relationships amongst workers. Third, collective accountability is introduced at the outside ellipse, fulfilling the collective level of inclusion (e.g., employment, income, education). It is about organizations contributing valuable resources to the disenfranchised community which, in turn, develops a pool of resources for the organization. By developing valuable resources for the community, a more peaceful community is created which promotes positive relationships and collaborations between the organization and the community (the relational level of inclusion), and facilitates a more independent livelihood in the community (the individual level of inclusion). Simultaneously, the organization can grow future human resources (e.g., employees, customers) to feed into its own growth. Finally, but not least, structural accountability is introduced across two ellipses, thus signifying the managerial structural governance in coordinating inclusive activities between HQ and local communities by tying together different levels of inclusion. Ensuring the structural means of communications between HQ and local communities, provides a system operation that equalizes power in decision-making for the collective prosperity of organizations and communities. As a whole by developing a normative inclusion theory around creation of community inclusive organizations, this study has highlighted a new thinking in business and society nexus theorizing, moving away from one-sided organizational perspective of inclusion toward a community empowering perspective of inclusion that sees business and society as inseparable organisms for creating inclusive community.

Our framework also alerts us to certain caveats in relation to inclusive efforts of organizations within the unique contextual factors of developing countries such as weak institutions, high level of poverty, high dependence of community members on organizations, and competing interests of stakeholders. In light of this context, the four types of managerial accountability proposed in this article is designed as a basis to build a constructive stakeholder 
dialogue and simultaneously to broaden the scope of accountability for managers and communities as a whole for mutual benefit.

\section{Theoretical Implications}

This study has theoretical implications for several streams of research. First, we introduce the community psychology perspective to inclusion theories pertaining to normative theory and superordinate values of inclusive organizations, and more specifically managerial accountabilities for heightening business and society nexus theories. This perspective promotes diversity and inclusion in the intersection of business and society. Including the community psychology perspective in inclusion opens up the avenues to revise possible assumptions by getting to know the world of the other (Trickett, 2009). Our study thus extends inclusion research which is not only ascertained by the internal validity of research within business, but also by the external ecological validity from a community perspective (cf., Tobes, 2005, as cited in Trickett, 2009). By seeking the ecological validity of inclusive organizations, organizations can move beyond an insular perspective, of how diversity within an organizational context contributes to greater business success, as well as community development by integrating a community-wide perspective. Our study suggests inclusion is a multiple level (individual, relational, collective and structural) and multi-dimensional (role of givers, beneficiaries and other stakeholders) concept which involves personal empowering, relationship building, resource exchange and structural governance facilitated by those who include (e.g., the organization) and those who are included (e.g., minority members). The expanded concept of inclusion, as suggested in this study, provides future studies with an opportunity to undertake a more nuanced approach to include minorities within various business and community contexts. 
Second, this study extends the current trajectories on community engagement research concerning the need to enlarge the scope of accountability beyond accountability standards reporting by organizations (c.f., Rasche \& Esser, 2006). Moving beyond discrete practices of accountability reporting and diversity initiatives (e.g., recruitment and affirmative action programs) for promoting inclusive organizations, our work highlights four dimensions of managerial accountabilities - cultural, relational, collective and structural interventions - to facilitate constructive stakeholder dialogue/evaluation and to empower disenfranchised community lives while benefiting business operations (cf., DiTomaso et al., 2007).

Third, this study extends the community psychology literature regarding its superordinate accountability and holism values for improving the lives of the oppressed by understanding the role of managerial accountabilities (Trickett, 2009). By establishing four types of managerial accountabilities, we have clarified the role of business particularly within the developing county contexts on how managers can constructively build stakeholder dialogue to develop mutually beneficial collaboration between organizations and communities for advancing their regional socio-economic development as a whole (Nelson \& Prilleltensky, 2010).

\section{Practical Implications}

We contend that the community-inclusive framework established in this study will contribute to the understanding of organization-community linkages in which stakeholders become committed to working together for each other's prosperity (Tyler, 2007). In order to develop a community inclusive organization, this framework provides a basis for stakeholder dialogue and hold organizations or communities accountable for their actions and plans (Dalton et al., 2007). Placing inclusion and empowerment as a core objective of community psychology (Zimmerman, 2000), this framework facilitates "helping people to help themselves" by 
focusing on a point of joint evaluation and to find mutually beneficial and sustainable outcomes for communities and businesses (Scott \& Wolfe, 2015 p, 334). The evaluation based on the framework also generates process - and outcome - oriented information that heightens an organization's sensitivity to its responsibility to the community and to itself (Dalton et al., 2007).

The community-embedded inclusion framework for organizations supports this goal in light of inclusion in various organizational and community boundary-crossing contexts. By grounding our analysis on the theories of community psychology, empowerment evaluation, the managerial accountabilities introduced in this study provide the key normative principles for managers to advance their community inclusion in different contexts. As the managerial responsibilities to look after poor communities along the supply chain have been widely scrutinized (Amaeshi, Osuji \& Nnodim, 2008), this study provides the key principles for organizations through the proposed managerial accountabilities-collective, cultural, relational and structural — as to how to include disenfranchised communities where business operates.

We further suggest that the key principles of community inclusion defined in this study are applicable to the inclusion of other community groups which are often marginalized by their lack of access to the workforce. The community groups may include people with disabilities; those who are lesbian, gay, bisexual or transgender (LGBT); refugees or asylum seekers; and racial minorities. When top managers operate with a community-inclusive norm to include disenfranchised communities in their business decisions, we expect that they will inherently include the multiple disadvantaged community groups. 


\section{Limitations and Future Research}

We acknowledge several limitations of this study. First, we acknowledge our limitation to our exploration of a community inclusive approach in a situation where APP has asymmetrically greater power than community, anchored in the global legacy of colonialism. APP within the context studied is no doubt a powerful player, which thus amplifies the importance of managerial accountabilities in creating the normative organizational framework for community inclusion.

Second, we acknowledge that our findings may not be fully applicable to organizations that operate in developed countries. Nevertheless, by focusing on Indonesia, our findings have contributed to theory development in relations to workplace inclusion, community empowerment and community psychology literature, which may find relevance for developed countries. Third, although we tried as much as possible to report our data objectively, we must acknowledge that the ethical and theoretical positions taken in analyzing the data may have influenced the outcome of this research and, therefore, our findings "can never be truly objective" (Miles, Huberman \& Saldaña, 2013, pp. 11). We also acknowledge that our findings may not be uniform across all APP projects as we selected some exemplary community inclusive projects. Further, despite our probing attempts, our data obtained from employees or beneficiaries might have been biased as they report favorable responses for their employers or givers. By having a community psychology perspective of inclusion as our anchor for our field study, however, our resulting framework is broad enough and is based on the acknowledgement of the potential challenges that organizations face in their community inclusion attempts.

An area of research worthy of future investigation would be to determine how organizations invite disenfranchised community members to create innovations for business growth. Another possible research avenue might be to listen to the voices of different community groups on how organizations can customize their inclusion efforts in different 
nations or social contexts. Further, an assessment could be made of the multiple-sector partnership model and how different stakeholders may complement each other's strengths in fostering community development. Future research could also determine how multi-level and multi-dimensional inclusion, as reported in this study, might apply to the inclusion effort inside and outside various organizations. Future studies could also explore and test the proposed framework in other organizations in different sectors. 


\section{References}

Amaeshi, K. M., Osuji, O. K., \& Nnodim, P. (2008). Corporate social responsibility in supply chains of global brands: A boundaryless responsibility? Clarifications, exceptions and implications. Journal of Business Ethics, 81(1), 223-234.

Asia Pulp \& Paper (APP) (2013a). Social responsibility. Retrieved June 13, 2014 from http://www.asiapulppaper.com/sustainability/social-responsibility.

Asia Pulp \& Paper (APP) (2013b). APP vision 2020: Sustainability roadmap, executive summary. Jakarta, Indonesia APP.

Asia Pulp \& Paper (APP) (2013c). Community project. Jakarta, Indonesia APP.

Asia Pulp \& Paper (APP) (2013d). Sustainability. Retrieved June 13, 2014 from http://www.asiapulppaper.com/sustainability

Asia Pulp \& Paper (APP) (2013e). Community engagement. Retrieved June 13, 2014 from http://www.asiapulppaper.com/sustainability/social-responsibility/communityengagement

Avery, D. R., McKay, P. F., Wilson, D. C., \& Volpone, S. (2008). Attenuating the effect of seniority on intent to remain: The role of perceived inclusiveness. Paper presented at the Academy of Management Conference, Anaheim, CA.

Bell, M.P., Özbilgin, M. F., Beauregard, A. T., \& Sürgevill, O. (2011). Voice, silence, and diversity in 21st century organizations: Strategies for inclusion of gay, lesbian, bisexual, and transgender employees. Human Resource Management, 50(1), 131-146.

Benioff, M., \& Southwick, K. (2004). Compassionate capitalism. Franklin Lakes, NJ: Career Press.

Bruton, G. D. (2010). Letter from the editor: Business and the world's poorest billion-The need for an expanded examination by management scholars. Academy of Management Perspectives, 24(3), 6-10.

Burton, M., Boyle, S., Harris, C., \& Kagan, C. (2007). Community psychology in Britain. In S. Reich, M. Riemer, I. Prilleltensky \& M. Montero (Eds.), International Community Psychology (pp. 219-237). NJ: Kluwer/Springer.

Carroll, A. B., \& Shabana, M. K. (2010). The business case for corporate social responsibility: A review of concepts, research and practice. International Journal of Management Reviews, 12(1), 85-105.

Chavez, C. I., \& Weisinger, J. Y. (2008). Beyond diversity training: A social infusion for cultural inclusion. Human Resource Management, 47(2), 331-350.

Cortesi, L. (2015). Constant conflict? Unresolved land disputes still haunt Asia Pulp and Paper. January $15 . \quad$ Retrieved March, $11, \quad 2016$ from http://www.ran.org/constant_conflict_unresolved_land_disputes_still_haunt_asia_pulp_and_ paper 
Dalton, E., Elias, M. J., \& Wandersman, A. (2007). Community psychology: Linking individuals and communities. Stamford, CT: Wadsworth.

Day, P., \& Klein, R. (1987). Accountabilities: Five public services, London, England: Tavistock.

DiTomaso, N., Post, C. \& Parks-Yancy, P. (2007). Workforce diversity and inequality: Power, status, and numbers. Annual Review of Sociology, 33(1), 473-501.

Donaldson, T., \& Preston. L. E. (1995). The stakeholder theory of the corporation: Concepts, evidence, and implications. Academy of Management Review, 20(1), 65-91.

Edwards, M., \& Sen, G. (2000). NGOs, social change and the transformation of human relationships: A 21st-century civic agenda. Third-World Quarterly, 21(4), 605-616.

Fernandez, R. M., \& Fernandez-Mateo, I. (2006). Networks, race, and hiring. American Sociological Review, 71(1), 42-71.

Fetterman, D. M., Kaftarian, S. J., \& Wandersman, A. (1996). Empowerment evaluation: Knowledge and tools for self-assessment and accountability. Thousand Oaks, CA: Sage.

Fetterman, D., \& Wandersman, A. (2007). Empowerment evaluation yesterday, today, and tomorrow. American Journal of Evaluation, 28(2), 179-198.

Fisher, R., \& Shragge, E. (2007). Contextualizing community organizing: Lessons from the past, tensions in the present, opportunities in the future. In M. Orr (Ed.), Transforming the city: Community organizing the challenge of political change (pp. 193-217). Lawrence, KS: University Press of Kansas.

Freeman, R. E. (1984). Strategic management: A stakeholder approach. Boston, MA: Pitman.

Frink, D. D., \& Klimoski, R. J. (2004). Advancing accountability theory and practice: Introduction to the human resource management review, special edition. Human Resource Management Review, 14(1), 1-17.

Fujimoto, Y., Rentschler, R., Le. H., Edwards, D., \& Härtel, C. E. J. (2014) Lessons learned from community organizations: Inclusion of people with disabilities and others British Journal of Management, 25(3), 518-537.

George, G., McGahan, A. M., \& Prabhu, J. (2012). Innovation for inclusive growth: Towards a theoretical framework and a research agenda. Journal of Management Studies, 49(4), 661683.

Gritten, D., \& Kant, P. (2007). Assessing the impact of environmental campaigns against the activities of a pulp and paper company in Indonesia. International Forestry Review, 30(4), 819834.

Hall, A. T., Bowen, M. G., Ferris, G. R., Royle, M. T., \& Fitzgibbons, D. E. (2007). The accountability lens: A new way to view management issues. Business Horizons, 50, 405-413.

Harrell, S. P., \& Bond, M. A. (2006). Listening to diversity stories: Principles for practice in community research and action. American Journal of Community Psychology, 37,(3-4) 365376. 
Hawe, P., Shiell, A. \& Riley, T. (2009). Theorising interventions as events in systems. American Journal of Community Psychology, 43, (3-4), 267-276.

Head, B. W. (2007). Community engagement: participation on whose terms?. Australian Journal of Political Science, 42(3), 441-454.

Himmelman, A. T. (2001). On coalitions and the transformation of power relations: Collaborative betterment and collaborative empowerment. American Journal of Community Psychology, 29(2), 277-284.

Hirsch, G. B., Levine, R. \& Miller, R. L. (2007). Using system dynamics modeling to understand the impact of social change initiatives. American Journal of Community Psychology, 39(3-4), 239-253.

Jacobides, M. G. (2005). Industry change through vertical disintegration: How and why markets merged in mortgage banking. Academy of Management Journal, 48(3), 465-498.

Jagdish, B. (2016). 'It will take time to build up trust again': Asia Pulp and Paper's Jose Raymond. 20 $0^{\text {th }} \quad$ Feb 2016. Retrieved April 7, 2016 from http://www.channelnewsasia.com/news/singapore/it-will-take-time-to/2531558.html

Jamali, D. (2007). The case for strategic corporate social responsibility in developing countries. Business and Society Review, 112(1): 1-27.

Kalev, A., Dobbin, F., \& Kelly, E. (2006). Best practices or best guesses? Assessing the efficacy of corporate affirmative action and diversity policies. American Sociological Review, 71(4), 589-617.

Kilby, P. (2006). Accountability for empowerment: Dilemmas facing non-governmental organizations. World Development, 34(6), 951-963.

Lee, T. W. (1999). Using qualitative methods to organize research. Newbury Park, CA: Sage.

Levine, R. L., \& Fitzgerald, H. (1992). Analysis of dynamic psychological systems: Basic approaches to general systems, dynamic systems, and cybernetics, Vol. 1. New York: Plenum Press.

Lirio, P., M. D. Lee, M. L. Williams, L. K. Haugen, and E. E. Kossek (2008). The inclusion challenge within reduced load professionals: The role of the manager. Human Resource Management, 47(3), 443-461.

Maitar, B (2013). Asia Pulp \& Paper: From confrontation to engagement. http://www.greenpeace.org/international/en/news/Blogs/makingwaves/asia-pulp-paperforest-conservation-policy/blog/47162/

Margolis, J., \& Walsh, J. (2003). Misery loves companies: Rethinking social initiatives by business. Administrative Science Quarterly, 48(2), 268-305.

Matten, D., \& Moon, J. (2008). "Implicit" and "explicit" CSR: A conceptual framework for a comparative understanding of corporate social responsibility. Academy of Management Review, 33(2), 404-424. 
Michelon, G., Boesso, G., \& Kumar, K. (2013). Examining the link between strategic corporate social responsibility and company performance: An analysis of the best corporate citizens. Corporate Social Responsibility and Environmental Management, 20(2): 81-94.

Miles, M. B., \& Huberman, A. M. (1994). Qualitative data analysis: An expanded source book. Thousand Oaks, CA: Sage.

Miles, M. B., Huberman, A. M., \& Saldaña, J. (2014). Qualitative data analysis: A methods sourcebook. Thousand Oaks, CA: Sage.

Miranti, R., Vidyattama, Y., Hansnata, E., Cassells, R., \& Duncan, A. (2013). Trends in poverty and inequality in decentralising Indonesia (Social, Employment and Migration Working Paper No. 148). Paris, France: OECD Publishing.

Mor Barak, M. E. (2013). Managing diversity: Toward a globally inclusive workplace. Thousand Oaks, CA: Sage.

Moritsugu, J. Vera, E., Wong F., Duffy, K. G. (2014). Community psychology. Toronto: Pearson.

Muthuri, J. N. (2008). Participation and accountability in corporate community involvement programmes: A research agenda. Community Development Journal, 43(2), 177-193.

Muthuri, J. N., Moon, J., \& Idemudia, U. (2012). Corporate innovation and sustainable community development in developing countries. Business \& Society, 51(3), 355-381.

Nelson, G., \& Prilleltensky, I. (2010). Community psychology: In pursuit of liberation and well-being. NY, New York: Palgrave Macmillan.

Nishii, H. L. (2013). The benefits of climate for inclusion for diverse groups. Academy of Management Journal, 56, 1754-1753.

Pearce, J. L. (2005). Organizational scholarship and the eradication of global poverty. Academy of Management Journal, 48(6), 970-972.

Pearce, J. L., Xin, K. M., Rao, A. N., \& Xu, Q. J. (2005). Why the rich get richer: The role of organizations in the wealth of nations. Paper presented at the Annual Meeting of the Academy of Management, Honolulu.

Pelled, H. L., Ledford G. E., Jr., \& Mohrman, A. S. (1999). Demographic dissimilarity and workplace inclusion. Journal of Management Studies, 36(7), 1013-1031.

Peterson, N. A., \& Zimmerman, M. A. (2004). Beyond the individual: Toward a nomological network of organizational empowerment. American journal of community psychology, 34(12), 129-145.

Plowman, D. A., Baker, L. T., Beck, T. E., Kulkarni, M., Solansky, S. T., \& Travis, D. V. (2007). Radical change accidentally: The emergence and amplification of small change. Academy of Management Journal, 50(3), 515-543.

Porter, M. E., \& Kramer, M. R. (2006). Strategy and society. Harvard Business Review, 84(12), 78-92. 
Prahalad, C. K. (2009). The fortune at the bottom of the pyramid, revised and updated 5th anniversary edition: Eradicating poverty through profits. Upper Saddle River, New Jersey: Wharton School Publishing.

Ragins, B. R., Gonzalez, J. A., Ehrhardt, K., \& Singh, R. (2012). Crossing the threshold: The spillover of community racial diversity and diversity climate to the workplace. Personnel Psychology, 65(4), 755-787.

Rappaport, J. (1977). Community psychology: Values, research, and action. New York: Holt, Rinehart and Winston.

Rappaport, J. (1995). Empowerment meets narrative: Listening to stories and creating settings. American Journal of Community Psychology, 23(5), 795-807.

Rasche, A., \& Esser, D. E. (2006). From stakeholder management to stakeholder accountability. Journal of business ethics, 65(3), 251-267.

Ravasi, D., \& Schultz, M. (2006). Responding to organizational identity threats: Exploring the role of organizational culture. Academy of Management Journal, 49(3), 433-458.

Reyes, E., \& Manibo, M. (2014). APP calls for collaboration to protect Indonesia's forests. Retrieved May 1, 2013 from http://www.eco-business.com/news/app-calls-collaborationprotect-indonesiasforests/?utm_medium=email\&utm_campaign=Feb\%2012\%20newsletter\&utm_content=Feb $\% 2012 \% 20$ newsletter+Version+A+CID_0babf11d6740c8cdc177477a2a2a3cb6\&utm_source =Campaign\%20Monitor\&utm_term=READ\%20FULL\%20STORY

Roberson, Q. M. (2006). Disentangling the meanings of diversity and inclusion in organizations. Group and Organizational Management, 31, 212-236.

Schein, E. H. (1984). Coming to a new awareness of organizational culture. Sloan Management Review, 25(2), 3-16.

Schlenker, B. R., \& Weigold, M. F. (1989). Self-identification and accountability. In P. Rosenfeld (Ed.), Impression management in the organization (pp. 21-43). Hillsdale, NJ: Lawrence Erlbaum Associates.

Scott, V., \& Wolfe, S. (2015). Community Psychology: Foundations for practice. California: Sage.

Seidman, E. (1988). Back to the future, community psychology: Unfolding a theory of social intervention. American Journal of Community Psychology, 16(1), 3-24.

Sherman, M. H., \& Ford, J. (2014). Stakeholder engagement in adaptation interventions: an evaluation of projects in developing nations. Climate Policy, 14(3), 417-441.

Shankleman, J. (2013). Can Asia Pulp and Paper really end deforestation? Retrieved May 12, 2014, from www.businessgreen.com/bg/feature/2299889/can-asia-pulp-paper-really-enddeforestation. 
Shore, L. M., Randel, A. E., Chung, B. G., Dean, M. A., Ehrhart, K. H., \& Singh, G. (2011). Inclusion and diversity in work groups: A review and model for future research. Journal of Management, 37(4), 1262-1289.

Sonnenfeld, D.A. (2000). Contradictions of ecological modernisation: Pulp and paper manufacturing in South-East Asia. Environmental Politics, 9(1), 235-256.

Sweeney, L. (2007). Corporate social responsibility in Ireland: Barriers and opportunities experienced by SMEs when undertaking CSR. Corporate Governance, 7(4), 516-523.

Trickett, E. J. (1996). A future for community psychology: The contexts of diversity and the diversity of contexts. American Journal of Community Psychology, 24(2), 209-234.

Trickett, E. J. (2009). Community psychology: Individuals and interventions in community context. Annual Review of Psychology, 60, 395-419.

Tyler, F. (2007). Developing prosocial communities across cultures. New York: Springer.

United Nations Development Program (UNDP). (2013). Human development report. The real wealth of nations: Pathways to human development, New York: United Nations.

Vurro, C., Russo, A., \& Perrini, F. (2009). Shaping sustainable value chains: Network determinants of supply chain governance models. Journal of Business Ethics, 90, 607-621.

Waddock, S.A., \& Boyle, M. (1995). The dynamics of change in corporate community relations. California Management Review, 37(4), 125-140.

Wandersman, A., Keener, D. C., Snell-Johns, J., Miller, R. L., Flaspohler, P., Livet-Dye, M., ... \& Robinson, L. (2004). Empowerment evaluation: Principles and action. Participatory community research: Theories and methods in action, 139-156.

Wasserman, I. C., Gallegos, P. V., \& Ferdman, B. M. (2008). Dancing with resistance: Leadership challenges in fostering a culture of inclusion. In K.M. Thomas (Ed.), Diverse resistance in organizations (pp. 175-200). New York: Taylor and Francis Group, Lawrence Erlbaum.

Yin, R. K. (2003). Case study research: Design and methods (3rd ed.). Thousand Oaks, CA: Sage.

Zimmerman, M. A. (2000). Empowerment theory: Psychological, organizational and Ecommunity levels of analysis. In J. Rappaport \& E. Seidman (Ed.), Handbook of community psychology (pp. 43-63). New York, NY: Kluwer Academic/Plenum. 
Figure 1: Community Inclusive Framework for Organizations

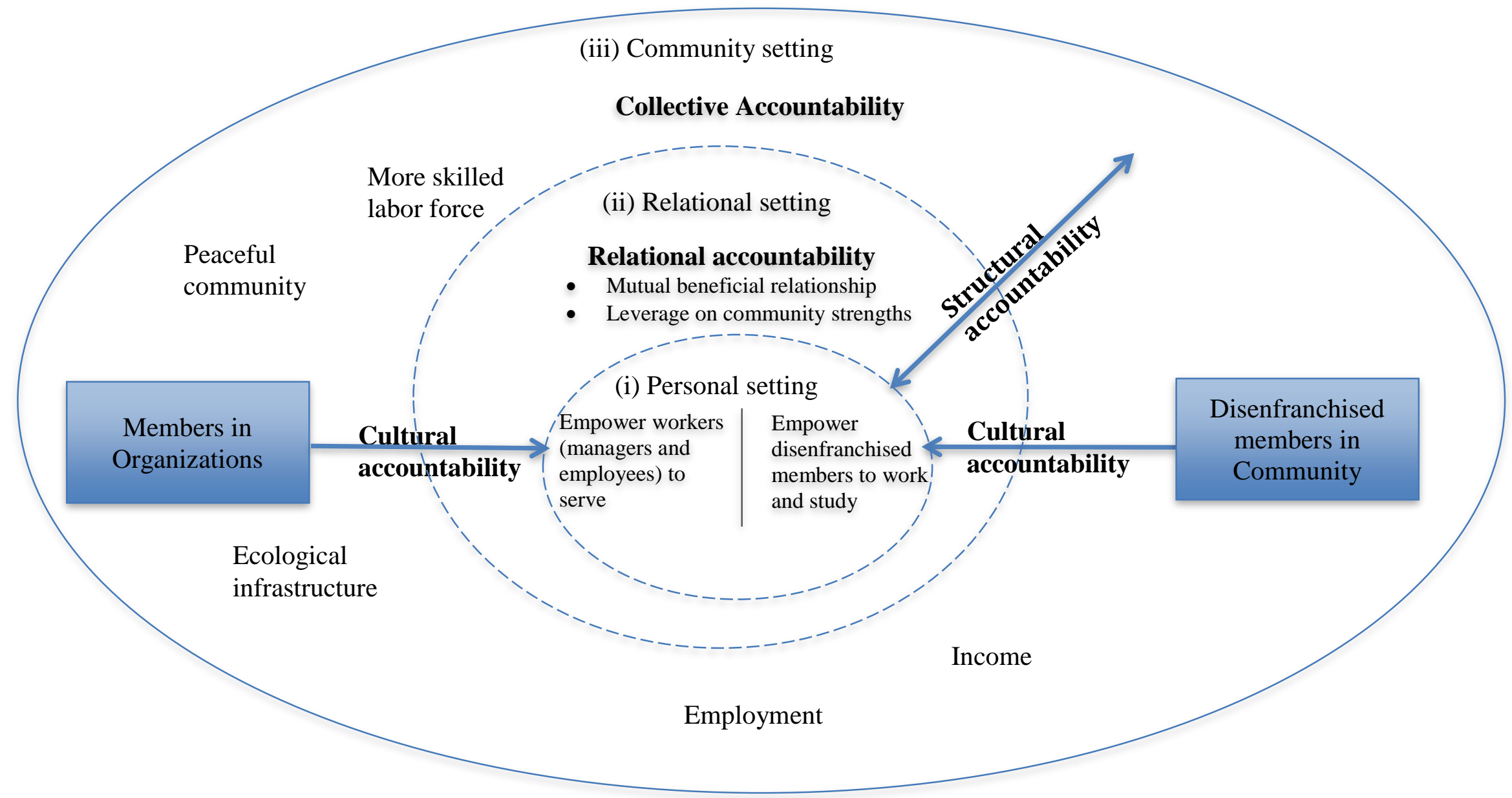

(i) Personal setting refers to individual attainment of positive identity, self-esteem and competence (individual level of inclusion inside and outside organizations)

(ii) Relational setting refers to positive relationships and collaboration at the intersection of organizations and community (relational level of inclusion)

(iii) Community setting includes community welfare such as employment, income, education and ecological infrastructure (collective level of inclusion) 
Table 1: Cultural, Collective, Structural and Relational Accountability of Managers

\begin{tabular}{|c|c|c|c|}
\hline & Themes & $\begin{array}{l}\text { Quotation } \\
(\mathrm{N}=)\end{array}$ & Sample account \\
\hline \multirow{5}{*}{ 当 } & $\begin{array}{l}\text { Cross-cutting } \\
\text { organization - } \\
\text { community } \\
\text { growth }\end{array}$ & $\begin{array}{l}\text { Manager (14) } \\
\text { Power point } \\
(6) \\
\text { APP } \\
\text { documents } \\
(18) \\
\text { Newspaper (4) }\end{array}$ & $\begin{array}{l}\text { The responsible development of its pulp and paper business is integral to the future prosperity of the } \\
\text { communities in which it operates. } \\
\text { Because environment here was quite tough for people's learning. So, when we put one mill in this area, there } \\
\text { were multiple demography, sociology, and anthropology needs. That's why supervisors were scared to use } \\
\text { people here. But I said to them, 'do not stereotype' there are still many 'diamond' people, capable and strong } \\
\text { people, in Serang. }\end{array}$ \\
\hline & $\begin{array}{l}\text { Changing values } \\
\text { of managers and } \\
\text { employees } \\
\text { inside and } \\
\text { outside of work } \\
\text { domains }\end{array}$ & $\begin{array}{l}\text { Manager and } \\
\text { employee (12) } \\
\text { APP } \\
\text { documents (3) }\end{array}$ & $\begin{array}{l}\text { I am now more empathetic and share everything with people here. } \\
\text { I fulfill my calling to make others' lives better, inclusion is about others' lives instead of mine. } \\
\text { I see many opportunities for myself to do good things for the societies and mainly the management has been } \\
\text { very supportive for us, that makes me feel that I can be here. }\end{array}$ \\
\hline & \multirow[t]{3}{*}{$\begin{array}{l}\text { Positive effects } \\
\text { on personal } \\
\text { identity, values } \\
\text { and } \\
\text { independence }\end{array}$} & $\begin{array}{l}\text { Employees } \\
\text { beneficiaries } \\
\text { community (5) }\end{array}$ & $\begin{array}{l}\text { I have improved my mindset by having education here being part of this community. I can also improve my } \\
\text { economy to support my family. } \\
\text { When I take school in this company there has been change. This is useful to change my future and I can } \\
\text { transfer my knowledge into the community. }\end{array}$ \\
\hline & & $\begin{array}{l}\text { Community } \\
\text { beneficiaries } \\
(8) \\
\text { Newspaper (1) }\end{array}$ & $\begin{array}{l}\text { I used to go to Arabic country for work to be servant. Instead of being that, it is much better here, family is OK } \\
\text { and still making money. } \\
\text { It is giving me opportunities to build skill as well. I am happy to have this skill because who knows someday if } \\
\text { there is no more support from APP I can get to do it myself, to choose what kind of fish to be put aside. }\end{array}$ \\
\hline & & $\begin{array}{l}\text { Community } \\
\text { non- } \\
\text { beneficiaries } \\
\text { (3) }\end{array}$ & $\begin{array}{l}\text { I am inspired by the company. I am not staff but the company buys clothes from my shop. } \\
\text { My business is supported by the company staff photocopying staff. }\end{array}$ \\
\hline
\end{tabular}




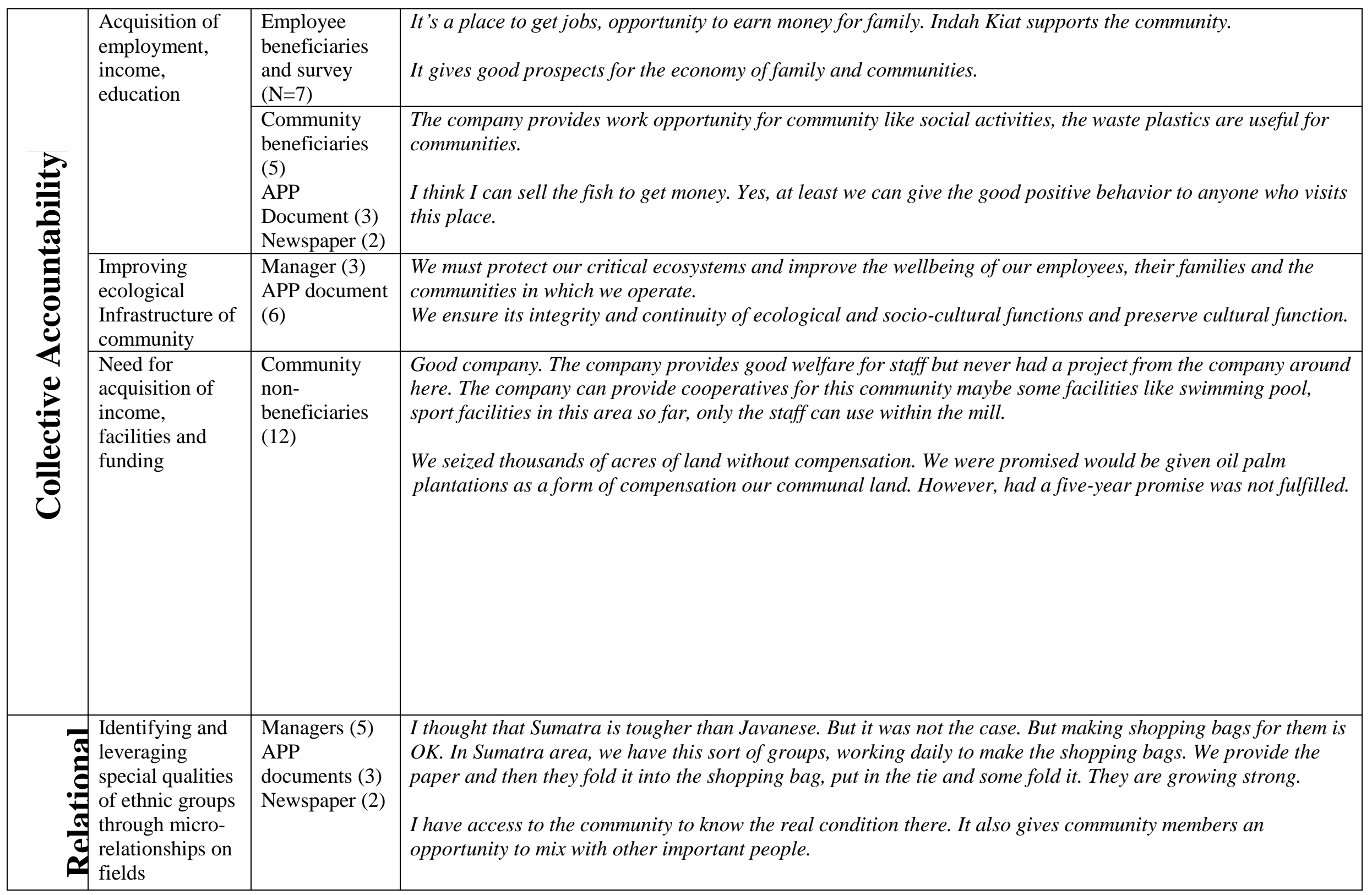




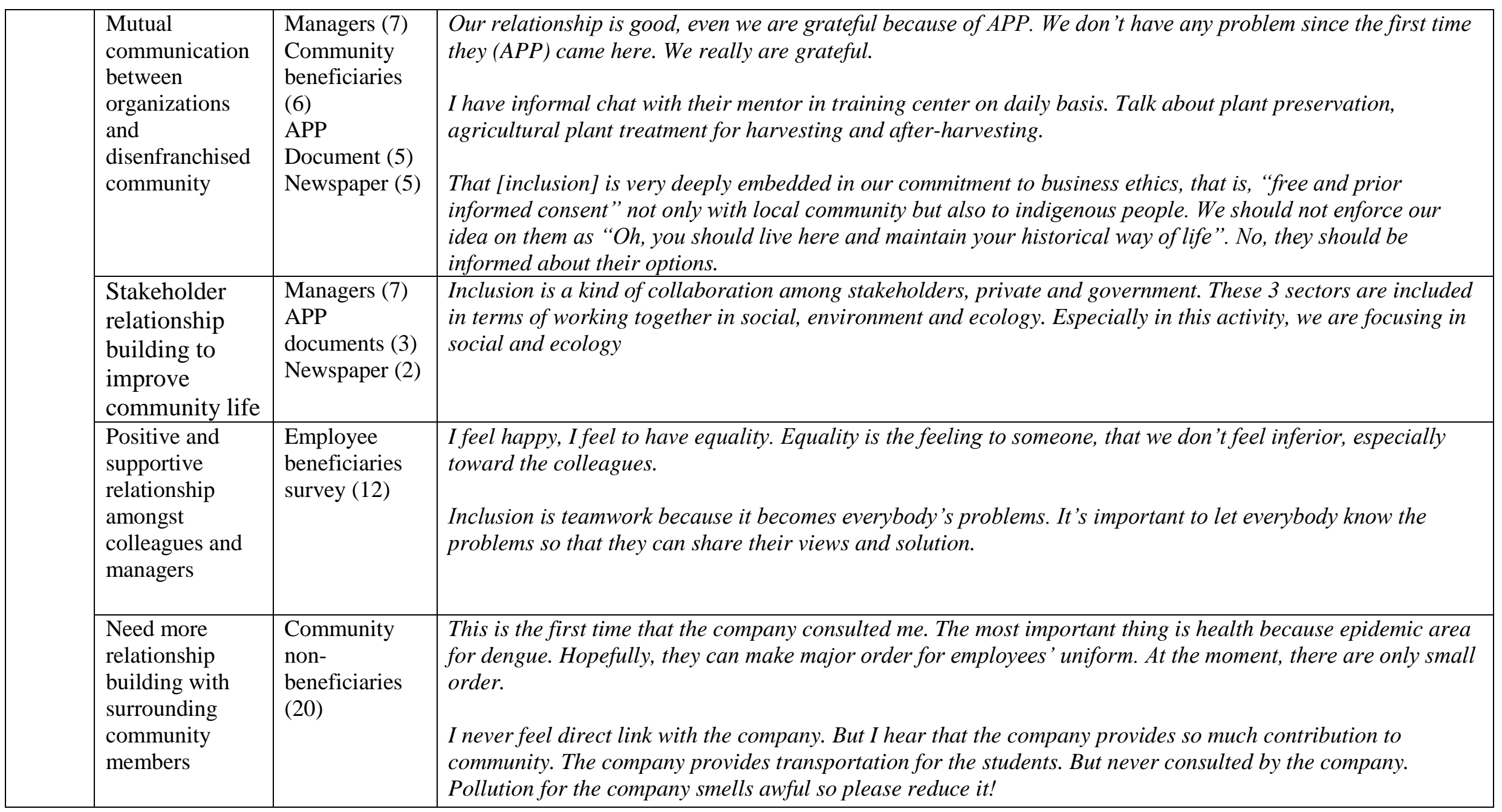




\begin{tabular}{|c|c|c|c|}
\hline \multirow{4}{*}{ 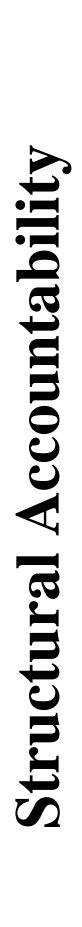 } & $\begin{array}{l}\text { Planning, } \\
\text { evaluation, } \\
\text { measurement, } \\
\text { reporting } \\
\text { relationships } \\
\text { between HQ and } \\
\text { supply chain site }\end{array}$ & $\begin{array}{l}\text { Managers (6) } \\
\text { Power points } \\
\text { (7) } \\
\text { APP } \\
\text { documents (3) } \\
\text { Newspaper (9) }\end{array}$ & $\begin{array}{l}\text { What is our target? Environment, social, economy, and investment - I need to know. Then we need to set up a } \\
\text { roadmap of how to achieve them. All these targets and milestones need to be measured and verified. Then we } \\
\text { meet together, we review all individual targets, which ones that we need to concentrate on and prioritize. } \\
\text { Because basically we want to have a clear target that can be measured. That was the drive. } \\
\text { Before we start this activity, we engage in the in-depth study in the field so that we try to gather information we } \\
\text { need from all stakeholders, society, media, NGO's. After that, we do the analysis and then make the proposal. }\end{array}$ \\
\hline & $\begin{array}{l}\text { Selection } \\
\text { criteria for } \\
\text { beneficiaries }\end{array}$ & Managers (5) & $\begin{array}{l}\text { To select the beneficiaries, they need to be in need to support their family living and having a basic knowledge } \\
\text { of the field such as farming, as well as to demonstrate commitment to attend our training. } \\
\text { We select only fisherman with a fishery culture. Then, they need to be committed to be educated by us such as } \\
\text { this agricultural system of fish hatching with this technology. }\end{array}$ \\
\hline & $\begin{array}{l}\text { Need for social } \\
\text { investment } \\
\text { measures }\end{array}$ & Managers (3) & $\begin{array}{l}\text { Haven't actually quantified yet. We are still in process of getting there - of being able to quantify properly what } \\
\text { kind of a return of investment we are getting. We need to know more, because social investment concept is } \\
\text { something new for us and for everybody in Indonesia. }\end{array}$ \\
\hline & $\begin{array}{l}\text { Need for } \\
\text { specific } \\
\text { appointment for } \\
\text { community } \\
\text { improvement }\end{array}$ & Managers (2) & $\begin{array}{l}\text { Good, but I recognize that this group of people are not only responsible for community projects as part of CSR, } \\
\text { they are doing different kinds of activities, taking care of the imports, exports or other activities and this is } \\
\text { distracting their focus. }\end{array}$ \\
\hline
\end{tabular}


